\title{
Immunization of ovariectomized ewes against progesterone, oestrogen or cortisol to detect effects of adrenal steroids on reproduction
}

\author{
N. R. Adams*, S. Atkinson* ${ }^{*}$, R. M. Hoskinson $\dagger$, J. A. Abordi*, \\ J. R. Briegel*, M. Jones† and M. R. Sanders* \\ *CSIRO Division of Animal Production, Wembley, WA 60I4, Australia; and \\ †CSIRO Division of Animal Production, Blacktown, NSW 2148, Australia
}

\begin{abstract}
Summary. Ovariectomized ewes were immunized against cortisol, oestrogen or progesterone to determine whether steroids of non-ovarian origin occur in sufficient amounts to influence the reproductive system. Ewes immunized against oestrogen (oestrone + oestradiol) had smaller uteri $(P<0.05)$ and a lower concentration of oestradiol in uterine tissue $(P<0.05)$, while the adrenal gland was heavier $(P<0.05)$. In the peripheral plasma of immunized ewes, the concentration of $\mathrm{FSH}$, but not $\mathrm{LH}$, was increased $(P<0.05)$. Ewes immunized against cortisol also had smaller uteri $(P<0.05)$ and heavier adrenal glands $(P<0.05)$, but gonadotrophins and the concentration of oestradiol in the uterus were unaffected. Immunization against progesterone, or injection with synthetic glucocorticoids, did not affect any of the characteristics measured.

We conclude that the adrenal gland of the ewes produced sufficient oestrogen or aromatizable androgen to have significant effects on the reproductive system. In contrast, adrenal production of progesterone did not produce detectable biological effects. Immunization against cortisol did affect the reproductive system, but the mechanism of this action could not be determined.
\end{abstract}

Keywords: ewe; adrenal; uterus; steroids; gonadotrophins

\section{Introduction}

The adrenal gland secretes many steroidal hormones, including glucocorticoids, mineralocorticoids, progestagens, oestrogens and aromatizable androgens. In a number of species it has been shown that some of these hormones are secreted in amounts sufficient to influence the reproductive system. For example, in women it is estimated that up to half the circulating oestrogens can be of adrenal origin (Ellison, 1984), while in the rat up to half the progesterone at some stages of the oestrous cycle is produced by the adrenal gland (Shaikh \& Shaikh, 1975). There have been few studies on the role of adrenal steroids in reproduction in sheep.

Adrenalectomy increased the concentration of oestrogen receptors and decreased the concentration of oestradiol in the uterus of ovariectomized ewes (Atkinson \& Adams, 1988) but had little effect on LH secretion (Montgomery et al., 1987; Atkinson \& Adams, 1988). As pointed out by Montgomery et al. (1987), adrenalectomy is a major surgical procedure in the ewe, and requires maintenance treatment with relatively large doses of glucocorticoid steroids. We have, therefore, used a different method to examine in more detail possible effects of steroids of adrenal origin on the uterus. The large number of oestrogens or aromatizable androgens secreted by the adrenal, 
together with the very low concentrations of oestradiol in the peripheral plasma of ovariectomized ewes, make it impractical to attempt to measure the effective oestrogenic stimulation to the uterus or the brain directly. Accordingly, the problem was approached indirectly by immunizing ovariectomized ewes against various classes of steroid hormones, and examining the ensuing effects.

Measurable amounts of progesterone are secreted by the sheep adrenal (De Silva et al., 1983), and so an initial study examined ovariectomized ewes immunized against progesterone or cortisol. A second study examined in greater detail ewes immunized against cortisol and also examined ewes immunized against a mixture of oestrone and oestradiol to block the oestrogenic effects of adrenal oestrogens or aromatizable androgens. Finally, we injected some ovariectomized ewes with the synthetic glucocorticoid dexamethasone, to examine directly for possible glucocorticoid effects on the uterus.

\section{Materials and Methods}

Experiment 1. During seasonal anoestrus (September), 45 5-year-old multiparous Merino ewes were randomly allocated to 3 groups of 15 and immunized with human serum albumin (HSA), progesterone-11 $\alpha$-ol-hemisuccinateHSA, or cortisol-3-(O-carboxymethyl)oxime-HSA. Ewes were injected at 4 subcutaneous sites with $1 \mathrm{mg}$ antigen emulsified in Freund's complete adjuvant (total volume $2 \mathrm{ml}$ ). After 12 weeks, the ewes were ovariectomized under general anaesthesia, and at 13 weeks they were re-immunized. At Week 15, a blood sample was collected from the jugular vein to estimate antibody titre, and half the ewes in each group received a Silestrus progesterone implant (Abbott Laboratories, Eastwood, NSW, Australia). The ewes were killed at the abattoir 8 days later, and the reproductive tracts and adrenal glands were recovered. Tissues were stored on ice and weighed within $3 \mathrm{~h}$.

Experiment 2. During seasonal anoestrus (September), 40 non-parous 2-year-old Merino ewes were randomly allocated to 4 groups of 10 , and immunized as described above with HSA, cortisol-3-(O-carboxymethyl)oxime-HSA, cortisol-21-hemisuccinate-HSA, or a mixture of 17 $\beta$-oestradiol-3-(O-carboxymethyl)oxime-HSA and oestrone-3-Ocarboxymethylether-HSA. At Week 9, the ewes were ovariectomized under general anaesthesia, at Week 12 they were re-immunized, and at Week 14 the ewes were fitted with jugular cannulae and blood samples taken every 15 min for $4 \mathrm{~h}$. The ewes were then killed by an overdose of barbiturate anaesthetic and the reproductive tracts and adrenal and pituitary glands were collected. Tissues were stored on ice and weighed within $30 \mathrm{~min}$.

Experiment 3. In the breeding season (April), 12 non-parous 2-year-old Merino ewes were ovariectomized under general anaesthesia and 3 weeks later were injected i.m. with saline (6 ewes) or $3 \mathrm{mg}$ dexamethasone (Dexadreson; Intervet, Lane Cove, NSW, Australia) (6 ewes) daily for 7 days. Ewes were killed by an overdose of barbiturate $24 \mathrm{~h}$ after the last injection, and the uteri were collected onto ice and weighed within $30 \mathrm{~min}$.

Assays. LH was measured in plasma samples, collected at 15-min intervals for $4 \mathrm{~h}$, using a double-antibody radioimmunoassay (Martin et al., 1980). The LH standard in this assay (PNRS-M3) is equivalent to 2.5 i.u. NIH-LHSI per mg (Oldham et al., 1978). Non-specific binding was $3 \cdot 12 \%$ and the sensitivity of the assay was $0 \cdot 15 \mathrm{ng} /$ tube. Two pools of plasma containing $3.36 \pm 0.34$ and $19.78 \pm 1.40 \mathrm{ng} \mathrm{LH} / \mathrm{ml}$ were included in the assay for the calculation of the inter-assay coefficients of variation, which were $10 \cdot 1 \%$ and $7 \cdot 1 \%$. Intra-assay coefficient of variation was 3.5\%. The LH profiles were analysed for pulses using a modified version of the 'Pulsar' algorithm (Merriam \& Wachter, 1982) developed for the Apple Mackintosh microcomputer (Munro; Elsevier-BIOSOFT, Cambridge, UK). The pulse frequency, mean pulse amplitude, and baseline values were calculated for each profile.

FSH was measured in plasma samples collected at $1-\mathrm{h}$ intervals over the 4-h bleeding period. Samples were assayed using a double-antibody radioimmunoassay provided by the pituitary agency of NIH and validated in our laboratory (Atkinson \& Adams, 1988). Non-specific binding was $<5 \%$ and the sensitivity of the assay $0.09 \mathrm{ng} /$ tube. Two plasma pools containing $0.83 \pm 0.03$ and $1.99 \pm 0.04 \mathrm{ng} \mathrm{FSH} / \mathrm{ml}$ were included in the assay for the calculation of intra-assay coefficient of variation, which was $6.8 \%$. All samples were analysed in a single assay to avoid inter-assay variation.

Oestradiol-17 $\beta$ was measured in extracts of uterine tissue using the single-antibody radioimmunoassay of McNatty et al. (1976), as modified by Atkinson et al. (1986). The extraction of oestradiol from the uterine tissues was carried out as described by Atkinson \& Adams (1988) with some modification. Briefly, $2-3 \mathrm{~g}$ uterine tissue were minced and homogenized in $5 \mathrm{ml}$ water. The homogenate was extracted twice with diethyl ether. The dried extract was defatted overnight with $5 \mathrm{ml} 70 \%$ methanol/water and then centrifuged at $4{ }^{\circ} \mathrm{C}$. The precipitated fat was washed with $1 \mathrm{ml}$ cold methanol, and the supernatants were pooled and dried under nitrogen. When the mixture was nearly dry it was extracted with $2 \mathrm{ml}$ diethyl ether, which was dried in assay tubes and assayed as previously described.

The non-specific binding was $4.5 \%$ and the sensitivity of the assay was $2.3 \mathrm{pg} /$ tube. A pool of uterine tissue was included for the calculation of interassay coefficient of variation, which was $19.0 \%$. Recovery from the extraction and defatting procedure was $64.0 \%$. 
Oestradiol receptors were measured in uterine tissue by Scatchard analysis, using concentrations of $\left[{ }^{3} \mathrm{H}\right]$ oestradiol between 0.1 and $10 \mathrm{nmol} / 1$, as described by Atkinson \& Adams (1988). The concentration of protein in uterine homogenate was estimated by the method of Lowry et al. (1951), using bovine serum albumin as a standard.

Antigens were synthesized by conjugating the relevant steroid acids to HSA by the dimide method in phosphate buffer-tetrahydrofuran (Lindner et al., 1972). The determination of antibody titres was similar to the method described by Abraham (1974).

Statistics. Values for titres were transformed to logarithms to obtain approximate normality of the data and then back transformed for presentation. Groups were compared by analysis of variance followed by Newman-Keuls comparisons of individual group means, when appropriate.

\section{Results}

\section{Experiment 1}

The immunization treatment produced relatively low titres, but these were sufficient to bring about biological effects. The mean (and s.e. range) anti-progesterone antibody titre in the ewes immunized against progesterone was 1244 (819-1889). In the ewes immunized against cortisol the mean anti-cortisol titre was 136 (106-173), with a cross-reaction against progesterone detected in only 1 of the 15 animals (titre 700). Immunization against cortisol increased the weight of the adrenal glands $(P<0.05)$, an effect which was blocked by exogenous progesterone (Table 1).

Table 1. Effects of progesterone treatment in ovariectomized ewes immunized against progesterone or cortisol

\begin{tabular}{|c|c|c|c|c|}
\hline $\begin{array}{l}\text { Immunization } \\
\text { group }\end{array}$ & $\begin{array}{l}\text { No. of } \\
\text { ewes }\end{array}$ & $\begin{array}{l}\text { Uterine } \\
\text { wt }(\mathrm{g})\end{array}$ & $\begin{array}{l}\text { Adrenal } \\
\text { wt }(\mathrm{g})\end{array}$ & $\begin{array}{l}\text { Uterine } \\
\text { oestradiol } \\
(\mathrm{pg} / \mathrm{g})\end{array}$ \\
\hline \multicolumn{5}{|l|}{ Untreated } \\
\hline Control & 8 & $27 \cdot 1 \pm 1 \cdot 7$ & $5.05 \pm 0.35$ & $17 \cdot 5 \pm 2 \cdot 0$ \\
\hline Progesterone & 8 & $28.2 \pm 1 \cdot 8$ & $5 \cdot 53 \pm 0 \cdot 28$ & $11 \cdot 8 \pm 2 \cdot 4$ \\
\hline Cortisol & 7 & $24 \cdot 0 \pm 2 \cdot 5$ & $6.28 \pm 0.47^{*}$ & $19 \cdot 2 \pm 2 \cdot 9$ \\
\hline \multicolumn{5}{|c|}{ Progesterone-treated } \\
\hline Control & 7 & $31 \cdot 5 \pm 3 \cdot 0$ & $5.51 \pm 0.63$ & $14 \cdot 6 \pm 1 \cdot 2$ \\
\hline Progesterone & 7 & $28 \cdot 1 \pm 1 \cdot 3$ & $5 \cdot 84 \pm 0 \cdot 36$ & $15 \cdot 8 \pm 3 \cdot 1$ \\
\hline Cortisol & 8 & $31 \cdot 9 \pm 2 \cdot 4$ & $5 \cdot 42 \pm 0 \cdot 14$ & $13 \cdot 7 \pm 2 \cdot 3$ \\
\hline
\end{tabular}

Values are mean \pm s.e.m.

${ }^{*} P<0.05$, compared with control value.

Immunization against progesterone did not affect the weight of the uterus (Table 1), while cortisol immunization tended to reduce uterine weight. Analysis of variance of the combined control and cortisol-immunized ewes indicated that exogenous progesterone increased uterine weight $(P<0.05)$. However, exogenous progesterone did not affect uterine weight in ewes immunized against progesterone (Table 1).

There were no significant effects of treatment on the concentration of oestrogen in the uterus.

\section{Experiment 2}

High titres of antibody were produced by all the immunization treatments in this study. The mean (and s.e. range) anti-oestradiol titre was 64729 (50 165-83 522) and the anti-oestrone titre was 223460 (183 231-272 521). The mean titre against cortisol-3-CMO was 2893 (2020-4142) and that against cortisol-21-hemisuccinate was 14073 (8991-22 026). Cross-reacting titres against progesterone for the last 2 groups were $12(6-26)$ and $173(80-374)$ respectively.

The two cortisol antigens produced similar effects in the ewes, and so the groups were pooled for statistical analysis. The weight of the adrenal glands was increased $(\boldsymbol{P}<\mathbf{0 \cdot 0 5})$ and the weight of 
the uterus was decreased $(P<0.05)$ in ewes immunized against oestrogen and in ewes immunized against cortisol (Table 2). Effects on pituitary weight and the concentration of protein in the uterus were not statistically significant. The concentration of oestradiol in the uterus was decreased $(P<0.05)$ in ewes immunized against oestrogen but was not affected by cortisol immunization.

Table 2. Effects of immunizing ovariectomized ewes against oestrogen or cortisol

\begin{tabular}{|c|c|c|c|c|c|c|}
\hline $\begin{array}{l}\text { Immunization } \\
\text { group }\end{array}$ & $\begin{array}{l}\text { No. of } \\
\text { ewes }\end{array}$ & $\begin{array}{l}\text { Uterine } \\
\text { wt (g) }\end{array}$ & $\begin{array}{l}\text { Adrenal } \\
\text { wt }(\mathrm{g})\end{array}$ & $\begin{array}{c}\text { Pituitary } \\
\text { wt (g) }\end{array}$ & $\begin{array}{l}\text { Uterine } \\
\text { protein } \\
(\mathrm{mg} / \mathrm{g})\end{array}$ & $\begin{array}{c}\text { Uterine } \\
\text { oestradiol } \\
(\mathrm{pg} / \mathrm{g})\end{array}$ \\
\hline Control & 10 & $13 \cdot 5 \pm 0.6$ & $3 \cdot 18 \pm 0 \cdot 14$ & $0.56 \pm 0.05$ & $38 \cdot 2 \pm 1 \cdot 3$ & $29 \cdot 0 \pm 4 \cdot 6$ \\
\hline Oestrogen & 10 & $10 \cdot 8 \pm 0.6^{*}$ & $3 \cdot 69 \pm 0 \cdot 18^{*}$ & $0.66 \pm 0.05$ & $40 \cdot 4 \pm 2 \cdot 3$ & $15 \cdot 0 \pm 2 \cdot 2^{*}$ \\
\hline Cortisol & 20 & $11.4 \pm 0.4^{*}$ & $3.72 \pm 0.09^{*}$ & $0.64 \pm 0.04$ & $36.5 \pm 0.8$ & $27 \cdot 0 \pm 3 \cdot 3$ \\
\hline
\end{tabular}

Values are mean \pm s.e.m.

${ }^{*} P<0.05$, compared with control value.

The concentration of FSH was increased $(P<0.05)$ in ewes immunized against oestrogen, but no treatment affected the secretion of LH (Table 3 ).

Table 3. Concentrations of LH and FSH in the plasma of ovariectomized ewes immunized against cortisol or oestrogen

\begin{tabular}{lccc}
\hline & \multicolumn{3}{c}{ Immunization group } \\
\cline { 2 - 4 } & $\begin{array}{c}\text { Control } \\
(\mathrm{N}=10)\end{array}$ & $\begin{array}{c}\text { Cortisol } \\
(\mathrm{N}=20)\end{array}$ & $\begin{array}{c}\text { Oestrogen } \\
(\mathrm{N}=10)\end{array}$ \\
\hline FSH & & & \\
$\quad$ Mean $(\mathrm{ng} / \mathrm{ml})$ & $9.36 \pm 0.61$ & $9.54 \pm 0.59$ & $13.04 \pm 1 \cdot 12^{*}$ \\
LH & & & \\
Pulse interval $(\mathrm{min})$ & $48.7 \pm 3.4$ & $51 \cdot 1 \pm 3 \cdot 7$ & $50.4 \pm 3.9$ \\
Amplitude $(\mathrm{ng} / \mathrm{ml})$ & $3 \cdot 18 \pm 0.33$ & $3.49 \pm 0.29$ & $3.05 \pm 0.44$ \\
Baseline $(\mathrm{ng} / \mathrm{ml})$ & $6.14 \pm 0.43$ & $5 \cdot 13 \pm 0.42$ & $7.08 \pm 0.89$ \\
\hline
\end{tabular}

Values are mean \pm s.e.m.

${ }^{*} P<0.05$, compared with control value.

\section{Experiment 3}

Treatment with dexamethasome did not significantly affect any of the uterine characteristics examined (Table 4).

Table 4. Effect of $3 \mathrm{mg}$ dexamethasone/day for 7 days on the uterus of ovariectomized ewes

\begin{tabular}{lccccc}
\hline Group & $\begin{array}{c}\text { No. of } \\
\text { ewes }\end{array}$ & Wt $(\mathrm{g})$ & $\begin{array}{c}\text { Protein } \\
(\mathrm{mg} / \mathrm{g})\end{array}$ & $\begin{array}{c}\text { Oestradiol } \\
(\mathrm{pg} / \mathrm{g})\end{array}$ & $\begin{array}{c}\text { Oestrogen receptors } \\
(\mathrm{pmol} / \mathrm{mg} \text { protein })\end{array}$ \\
\hline Control & 6 & $16.9 \pm 1.8$ & $3.31 \pm 0.02$ & $34.2 \pm 1 \cdot 7$ & $0.68 \pm 0.07$ \\
Treated & 6 & $14.9 \pm 1.3$ & $3.22 \pm 0.09$ & $37.9 \pm 6.9$ & $0.83 \pm 0.10$ \\
\hline
\end{tabular}




\section{Discussion}

This study shows that, in the ewe, non-ovarian sources of oestrogen can exert a measurable effect on the reproductive system: in ovariectomized ewes, immunized against oestradiol and oestrone, the weight of the uterus was decreased and the concentration of FSH in peripheral plasma was increased. In a similar study, Sanford (1987) found an increase in LH pulse frequency in castrated rams after more prolonged immunization against oestradiol but did not report data for FSH. In the present study, the reduced concentration of oestradiol in the uterus of immunized ewes supported both the effectiveness of the immunization treatment and the likelihood that the biological effects resulted from decreased oestrogenic stimulation. It is probable that the oestrogen was derived from the adrenal gland because these glands were enlarged in the immunized ewes and because Atkinson \& Adams (1988) have shown previously that adrenalectomy can decrease the concentration of oestradiol in the uterus. However, it is not known whether the adrenal glands act by secreting oestrogens directly, or by secreting androgenic steroids which are aromatized to oestrogen at other sites in the body.

The increase in weight of the uterus caused by progesterone supports the work of Kelly et al. (1976), who obtained similar results. The adrenal gland of the ewe secretes measurable amounts of progesterone (De Silva et al., 1983), but immunization against this hormone did not reduce uterine weight. De Silva et al. (1983) reported that adrenal production of progesterone resulted in circulating concentrations of $0.1 \mathrm{ng} / \mathrm{ml}$, whereas the Silestrus implants used in the present study produce plasma progesterone concentrations of around $1 \mathrm{ng} / \mathrm{ml}$ (G. B. Martin, personal communication) to mimic a normal luteal phase. Although the antibody titres achieved in Exp. 1 were low, the antibody levels were sufficient to block the response to exogenous progesterone from the implants (Table 1) and so should have been more than sufficient to block endogenous progesterone. It must be concluded that the amount of progesterone secreted by the adrenal gland is not sufficient to affect uterine weight.

The mechanism by which immunization against cortisol decreased the weight of the uterus in ovariectomized ewes (Tables 1 and 2) is not clear. The reduction in weight was not statistically significant in Exp. 1, possibly because the ewes were older and had been pregnant and borne lambs and so their uteri were larger, but more probably because the anti-cortisol titre was relatively low. It is unlikely that the decrease resulted from interference with the synthesis of adrenal oestrogens, because the concentration of oestradiol in the uterus of immunized ewes was normal (Table 2). As described above, it is also improbable that the effect resulted from interference with the activity of progesterone. Although glucocorticoid receptors in the uterus have been reported (Panko et al., 1981), injection with dexamethasone did not increase uterine weight (Table 4) and so it would appear that glucocorticoid activity does not influence uterine weight. The effect may result from an interaction between cortisol and progesterone or oestrogen. Complex interactions of this type have been reported. For example, the weight of adrenal glands was reduced in rats treated with medroxyprogesterone (Fell et al., 1977) in a manner similar to the suppression of adrenal hypertrophy caused by exogenous progesterone in the cortisol-immunized ewes shown in Table 1. However, no such interaction was seen in effects on uterine weight (Table 1). Cortisol is also suggested to increase (Johnson \& Dey, 1980) or decrease (Terakawa et al., 1985) responses to oestradiol, possibly depending on the doses used (Verga et al., 1975).

Treatment with dexamethasone can reduce concentration of oestrogen receptors in the uterus of the rat (Campbell, 1978) and the ewe (Atkinson \& Adams, 1988), but in the present study this was not observed. However, the earlier studies used extremely large amounts of glucocorticoid; Campbell (1978) administered $1 \mathrm{mg}$ dexamethasone to rats, while Atkinson \& Adams (1988) used adrenalectomized sheep in which exogenous glucocorticoids were used to replace the gluconeogenic effect of adrenal cortical steroids and medullary catecholamines. The dose of dexamethasone normally used in veterinary practice is much lower similar to that used in the present study 
( $3 \mathrm{mg} /$ ewe daily). This dose is sufficient to stimulate systems normally responsive to glucocorticoid hormones (Anon, 1973) and, when injected daily for 7 days into ewes of similar liveweight, this dose of dexamethasone resulted in a significant increase in liveweight compared with controls $(N$. $R$. Adams, S. Atkinson \& M. R. Sanders, unpublished data). At this dose, effects observed previously with grossly excessive amounts of dexamethasone were not observed. We suggest therefore that glucocorticoid hormones may not normally play a role in control of oestrogen receptors in the uterus in the ewe.

The role played by adrenal glands in modulating reproductive activity in the ewe has been a subject of speculation for many years. The adrenal glands secrete oestrogenic hormones or their precursors (Atkinson \& Adams, 1988) and the present study indicates that these hormones are secreted in sufficient amounts to affect the weight of the uterus and the secretion of FSH. However, the mechanisms controlling adrenal oestrogen secretion are not clear. Immunization against cortisol, which increased adrenal weight and presumably ACTH secretion, did not increase the concentration of oestradiol in the uterus. On the other hand, immunization against oestrogen increased adrenal weight, indicating that there may be some control over the amount of oestrogen secreted by the adrenal gland. It remains to be seen whether the adrenal secretion of oestrogen is modulated sufficiently to alter the function of the target organs.

We thank the NIADDK of the National Institutes of Health (Bethesda, MD, USA) for the materials for the FSH assay; Professor M. Jutisz (College de France, Paris, France) for the LH preparation; and Dr K. M. Henderson and Dr K. P. McNatty for the oestradiol antiserum for RIA. The work was supported in part by the Australian Wool Corporation.

\section{References}

Abraham, G.E. (1974) Radioimmunoassay of steroids in biological materials. Acta endocr., Copenh., Suppl. $183,7-42$.

Anon (1973) Martindale: the Extra Pharmacopoeia, 26th edn, p. 515. The Pharmaceutical Press, London.

Atkinson, S. \& Adams, N.R. (1988) Adrenal glands alter oestrogen activity in the uterus of ewes. $J$. Endocr. 118, 375-380.

Atkinson, S., Williamson, P., Kang, C.L. \& Carson, R.S. (1986) Steroid production and hCG binding by raminduced ovarian follicles in seasonally anoestrous ewes. J. Reprod. Fert. 78, 403-412.

Campbell, P.S. (1978) The mechanism of the inhibition of uterotrophic responses by acute dexamethasone pretreatment. Endocrinology 103, 716-723.

De Silva, M., Kaltenbach, C.C. \& Dunn, T.G. (1983) Serum cortisol and progesterone after administration of adrenocorticotropin and (or) prolactin to sheep. $J$. Anim. Sci. 57, 1525-1529.

Ellison, P.T. (1984) Correlations of basal oestrogens with adrenal androgens and relative weight in normal women. Annls Hum. Biol. 11, 327-336.

Fell, B.F., Campbell, R.M. \& Dinsdale, D. (1977) Adrenocortical involution in rats during oestrus synchronization with medroxyprogesterone. Res. vet. Sci. 22, 316-323.

Johnson, D.C. \& Dey, S.K. (1980) Role of histamine in implantation: dexamethasone inhibits estradiolinduced implantation in the rat. Biol. Reprod. 22, 1136-1141.

Kelly, R.W., Allison, A.J. \& Shirley, D.K. (1976) Interactions between phyto-oestrogens and steroids in the cervical mucus and uterine weight responses in ewes. Aust. J. agric. Res, 27, 101-107.

Lindner, H.R., Perel, E. \& Zeitlin, A. (1972) Specificity of antibodies to ovarian hormones in relation to the site of attachment of the steroid hapten to the peptide carrier. Steroids 19, 357-375.

Lowry, O.H., Rosebrough, N.J., Farr, A.L. \& Randall, R.J. (1951) Protein measurement with the Folin phenol reagent. J. biol. Chem. 143, 265-275.

Martin, G.B., Oldham, C.M. \& Lindsay, D.R. (1980) Increased plasma LH levels in seasonally anovular Merino ewes following the introduction of rams. Anim. Reprod. Sci. 3, 125-132.

McNatty, K.P., Baird, D.T., Bolton, A., Chambers, P., Corker, C.S. \& McLean, A. (1976) Concentration of oestrogens in human ovarian venous plasma and follicular fluid throughout the menstrual cycle. $J$. Endocr. 71, 77-85.

Merriam, G.R. \& Wachter, K.W. (1982) Algorithms for the study of episodic hormone secretion. Am. J. Physiol. 243, 310-318.

Montgomery, G.W., Martin, G.B., Locatelli, A. \& Pelletier, J. (1987) The effect of adrenalectomy on LH release in sheep during the anoestrous season. $J$. Endocr. 114, 437-442.

Oldham, C.M., Martin, G.B. \& Knight, T.W. (1978) Stimulation of seasonally anovular Merino ewes by rams. I. Time from introduction of the rams to the pre-ovulatory LH surge and ovulation. Anim. Reprod. Sci. 1, 283-290.

Panko, W.B., Clark, J.H. \& Walters, M.R. (1981) Glucocorticoid receptors: documentation in the rat uterus. J. Receptor Res. $2,29.45$ 
Sanford, L.M. (1987) Luteinizing hormone release in intact and castrate rams is altered with immunoneutralization of endogenous estradiol. Canad. $J$. Physiol. Pharmacol. 65, 1442-1447.

Shaikh, A.A. \& Shaikh, S.A. (1975) Adrenal and ovarian steroid secretion in the rat estrous cycle temporally related to gonadotropins and steroid levels found in peripheral plasma. Endocrinology 96, 37-44.

Terakawa, N., Shimizu, I., Aono, T., Tanizawa, O. \& Matsumoto, K. (1985) Dexamethasone suppresses estrogen action at the pituitary level without modulating estrogen receptor dynamics. J. Steroid Biochem. 23, 385-388.

Varga, B., Hraschek, A. \& Folly, G. (1975) Effects of ACTH on the uterine weight response to HCG in mice. J. Reprod. Fert. 42, 213-219.

Received 15 September 1989 